\title{
EVALUAREA TROMBOCITOZEI REACTIVE POSTSPLENECTOMIE LA PACIENTUL PEDIATRIC
}

\author{
Andreea Ligia Dincă , Cristina Oana Mărginean', Despina Baghiư1, Alina Grama1, \\ Horea Gozar ${ }^{2}$, Andreea Durlan', Mihai Stanca ${ }^{3}$, Raluca Damian ${ }^{4}$, \\ Mihaela Chinceşan ${ }^{1}$ \\ ${ }^{1}$ Clinica de Pediatrie I, Universitatea de Medicină şi Farmacie, Târgu-Mureş \\ ${ }^{2}$ Clinica de Chirurgie şi Ortopedie Pediatrică, \\ Universitatea de Medicină şi Farmacie, Târgu-Mureş \\ ${ }^{3}$ Universitatea de Medicină şi Farmacie, Târgu-Mureş \\ ${ }^{4}$ Clinica de Neonatologie I, Spitalul Clinic Județean de Urgență, Târgu-Mureş
}

\begin{abstract}
REZUMAT
Trombocitoza reprezintă creşterea numărului de trombocite peste $500.000 / \mathrm{mm}^{3}$. Obiectiv. Obiectivul acestui studiu este de a evalua frecvența şi severitatea trombocitozei reactive la pacienții pediatrici splenectomizați.

Material şi metodă. Am realizat un studiu retrospectiv în care au fost incluşi 20 de pacienți (4-16 ani) care au suferit o intervenție de splenectomie în intervalul 2006-2015. Criteriile de includere în studiu au fost: pacienți cu vârsta sub 18 ani, care au fost splenectomizați şi care au dezvoltat trombocitoză ulterior intervenției.

Rezultate. În lotul studiat, 80\% dintre pacienții splenectomizați (16) au dezvoltat o formă de trombocitoză; în 4 cazuri formă severă (trombocite $>1 \mathrm{milion} / \mathrm{mm}^{3}$ ), iar în 7 cazuri formă uşoară. Nu s-au observat diferențe semnificative în repartiția pe sexe a pacienților (9 de sex feminin şi 11 de sex masculin). La 13 dintre pacienți trombocitoza s-a remis după 30 de zile şi doar în 3 dintre cazuri episodul a durat $>360$ de zile. Fenomene trombotice s-au observat la un singur pacient din lotul studiat. Toți pacienții au beneficiat de măsuri de tromboprofilaxie şi hidratare, iar 2 cazuri au necesitat asociere terapeutică de Hidoxiuree.

Concluzii. Studiul nostru relevă o frecvență crescută a trombocitozei după splenectomie (80\%), cu un vârf maxim de incidență la 2-10 zile postchirurgical, trombocitoza fiind în general benignă şi cu remisie spontană; evenimente trombotice s-au semnalat într-un singur caz, iar trombocitoza severă a fost mai frecventă după splenectomia de cauză traumatică.
\end{abstract}

Cuvinte cheie: trombocitoză, splenectomie, copil

\section{INTRODUCERE}

Splina este un organ limfoid complex care, pe lângă funcția hematopoietică îndeplineşte şi alte roluri importante precum cel imunologic, de filtrare sanguină sau de rezervor celular. Indicațiile splenectomiei în pediatrie sunt strict precizate; cele mai frecvente sunt: bolile hematologice, splenomegalia simptomatică, masele tumorale splenice, hemoragia splenică, bolile neoplazice sau post-traumatice. Sindromul postsplenectomie se caracterizează printr-un grup de complicații care pot apărea după intervenţie şi cuprinde episoade infecţioase, anemie prin distrucție celulară sau trombocitoză (1). Trombocitoza se defineşte printr-un număr de plachete sanguine de peste $500.000 / \mathrm{mm}^{3}$ şi este depistată de cele mai multe ori accidental. Poate fi pri- mară sau esențială - atunci când există un fond mieloproliferativ cu transformare anormală a celulei hematopoietice, subtip care se complică frecvent cu fenomene tromboembolice (2). Pe de altă parte, trombocitoza mai poate fi şi reactivă - secundară unor afecțiuni infecțioase, inflamatorii, traumatice, neoplazice sau splenectomiei $(3,4)$. De obicei este o afecțiune benignă şi autolimitantă care rareori degenerează în hemoragii masive sau fenomene trombotice (4-6\% dintre cazuri); complicațiile de acest fel par a fi datorate mai mult unor anomalii calitative şi nu anomaliilor cantitative ale trombocitelor $(5,6)$.

Obiectivul acestui studiu este de a evalua frecvența şi severitatea trombocitozei reactive la pacienții pediatrici splenectomizați. 


\section{MATERIAL ŞI METODĂ}

Am efectuat un studiu retrospectiv în care au fost incluşi pacienţi splenectomizați, cu vârsta între 4 şi 16 ani, în perioada 2006-2015, în Clinica de Chirurgie şi Ortopedie Pediatrică, Târgu-Mureş, şi care au fost ulterior monitorizați în Clinica de Pediatrie I, Târgu-Mureş. Din 25 de pacienți splenectomizați în perioada respectivă, doar 20 au fost incluşi în studiu conform criteriilor de includere, şi anume: pacienți cu vârsta sub 18 ani, care au suferit o operație de splenectomie, independent de cauza subiacentă (purpură trombocitopenică imună - forma cronică, leucemie granulocitară cronică, anemie hemolitică microsferocitară, post-traumatic) şi care au dezvoltat trombocitoză de peste 500.000/ $\mathrm{mm}^{3}$ ulterior intervenției chirurgicale. Criteriile de excludere au constat în pacienți ai căror părinți nu au semnat consimțământul informat sau pacienți cu date clinico-biologice incomplete.

Scopul studiului a fost evaluarea pacienților din punct de vedere clinico-biologic (număr de trombocite, durata de timp între splenectomie şi apariţia trombocitozei, momentul remisiei, frecvența apariției episoadelor trombotice), precum şi conduita terapeutică aplicată. Severitatea trombocitozei a fost clasată astfel: forma uşoară $\left(600-800.000 / \mathrm{mm}^{3}\right)$, forma medie $\left(800.000-1 \mathrm{milion} / \mathrm{mm}^{3}\right)$, iar forma severă a inclus valori ale trombocitelor de peste 1 milion $/ \mathrm{mm}^{3}$.

\section{REZULTATE}

Lotul de studiu a inclus 20 de pacienți cu vârste cuprinse între 4 şi 16 ani. Vârsta medie a fost de 9,6 ani, iar repartitia pe sexe nu a relevat diferențe semnificative între pacienții de sex masculin (11) şi cei de sex feminin (9). Diagnosticul de fond pentru care s-a practicat splenectomia a fost fie de natură hematologică: purpură trombocitopenică imună - forma cronică (11 pacienți), anemie hemolitică microsferocitară (1 pacient), leucemie granulocitară cronică (1 pacient); fie de natură traumatică -7 pacienți (Tabelul 1).

Splenectomia a fost programată în 13 cazuri şi a fost efectuată în regim de urgență la 7 pacienți. Un procent de $80 \%$ dintre pacienții incluşi în studiul nostru (16 subiecți) au dezvoltat o formă de trombocitoză postsplenectomie subclasată astfel: 7 pacienți s-au încadrat într-o formă uşoară de trombocitoză; 5 pacienți în forma medie; iar 4 pacienți în forma severă, prezentând peste 1 milion de trombocite $/ \mathrm{mm}^{3}$ (Tabelul 2).

Splenectomia datorată unui fond hematologic s-a însoțit mai frecvent de forme uşoare de trombocitoză (5 cazuri din 9), în contrast cu splenectomia de cauză traumatică, la care s-au asociat mai frecvent forme severe de trombocitoză ( 3 din 7 cazuri). Intervalul mediu de timp din ziua efectuării splenectomiei şi până la apariția creşterii numărului de plachete sanguine a fost de 3,5 zile; cel mai precoce s-a observat debutul după 2 zile, iar cel mai tardiv în ziua a 10-a post chirurgical (Fig. 1).

Episodul de trombocitoză s-a remis între 1 şi 14 zile la 5 dintre pacienți, între 14 şi 30 de zile la 8 cazuri şi mai tardiv, după o perioadă de peste 360 de zile, la 3 dintre pacienți (Fig. 2).

Evenimente trombotice s-au semnalat la un singur pacient, la care s-a depistat ulterior şi un profil genetic pozitiv pentru hemofilie.

În ceea ce priveşte tratamentul administrat, toți pacienții au necesitat măsuri profilactice auxiliare sau terapie pentru reducerea numărului de trombocite. În toate cazurile s-au utilizat măsuri de hidratare intensă şi terapie profilactică cu Dipiridamol sau Heparină în PEV/Heparină cu greutate moleculară mică; în 2 cazuri - s-a asociat terapie citotoxică - Hydreea (Hidroxiuree) pentru a reduce numărul de trombocite. 10 subiecți au fost evaluați la 1 an, iar 4 pacienți la 2 ani postsplenectomie.

TABELUL 1. Diagnosticul de bază al pacienților pentru care s-a efectuat splenectomia

\begin{tabular}{|l|c|c|c|c|}
\hline DIAGNOSTIC DE BAZĂ & $\begin{array}{c}\text { Purpură } \\
\text { trombocitopenică imună } \\
\text { cronică }\end{array}$ & $\begin{array}{c}\text { Anemie hemolitică } \\
\text { microsferocitară }\end{array}$ & $\begin{array}{c}\text { Leucemie } \\
\text { granulocitară } \\
\text { cronică }\end{array}$ & $\begin{array}{c}\text { Cauze } \\
\text { traumatice }\end{array}$ \\
\hline Nr. pacienți: & 11 & 1 & 1 & 7 \\
\hline
\end{tabular}

TABELUL 2. Numărul de trombocite postsplenectomie

\begin{tabular}{|l|c|c|c|}
\hline TROMBOCITOZĂ & FORMĂ UŞOARĂ & FORMĂ MEDIE & FORMĂ SEVERĂ \\
\hline Număr trombocite & $600-800.000 / \mathrm{mm}^{3}$ & $800.000-1 \mathrm{milion} / \mathrm{mm}^{3}$ & $>1 \mathrm{milion} / \mathrm{mm}^{3}$ \\
\hline Cauze traumatice & 2 & 2 & 3 \\
\hline Cauze hematologice & 5 & 3 & 1 \\
\hline Total pacienți & $\mathbf{7}$ & $\mathbf{5}$ & $\mathbf{4}$ \\
\hline
\end{tabular}




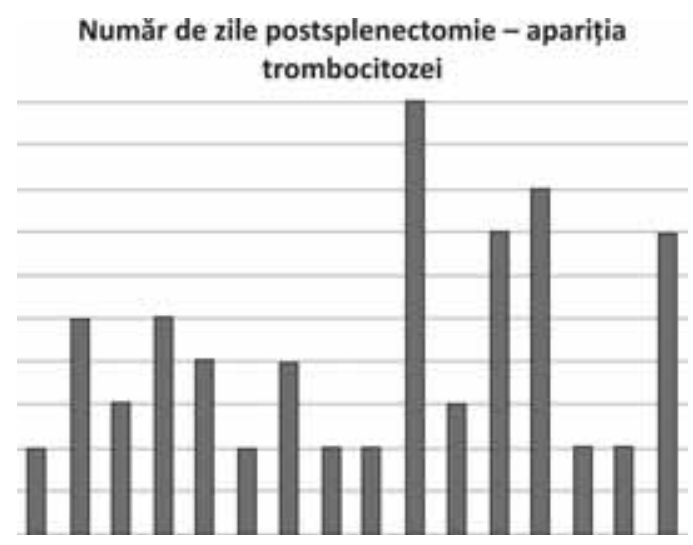

FIGURA 1. Intervalul de zile postsplenectomie - apariția trombocitozei

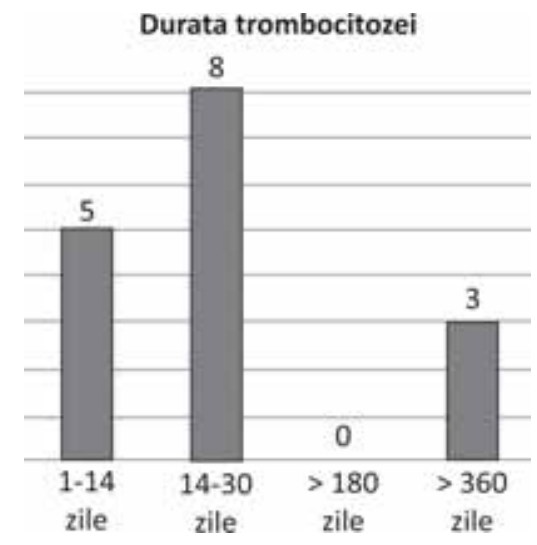

FIGURA 2. Durata până la remisia trombocitozei

\section{DISCUȚII}

Trombocitoza este o afecțiune frecvent întâlnită în copilărie, însă datorită unei simptomatologii nespecifice, de multe ori poate trece neobservată. Trombocitoza reactivă este rezultatul unei supraproducții de factori trombopoietici (în principal Inter Leukina-6) care acționează la nivelul megakariocitelor sau a precursorilor lor; acest fenomen se observă în procesele infecțioase, inflamatorii, maligne sau traumatice $(7,8)$. Tratamentul patologiei de fond duce de cele mai multe ori la remisia trombocitozei reactive, fără riscul altor manifestări trombotice; există însă şi cazuri cu hiperagregare plachetară şi care necesită profilaxie antiagregantă sau, în cazuri extreme, utilizarea de agenți citoreductivi (Hydroxiuree, Anagrelid) sub stricta monitorizare a numărului de trombocite $(9,10)$.

Splina joacă un rol major atât în reglarea, cât şi în distrucția trombocitelor, motiv pentru care trombocitoza este frecvent asociată hiposplenismului (11). Incidenţa trombocitozei reactive postsplenectomie a fost de $80 \%$ în studiul nostru, valoare comparabilă cu cea de $75 \%$ analizată într-un alt studiu care a fost realizat pe 318 pacienți, existând o dife- rență între incidența manifestărilor trombotice în studiul citat $(2,83 \%)$ şi valoarea de $6 \%$ din lotul nostru de studiu (12). Literatura de specialitate evidențiază o asociere între complicațiile tromboembolice şi trombocitoza persistentă postsplenectomie în $13 \%$ dintre cazuri (13). Factorii de risc cei mai frecvent incriminaţi în favorizarea complicațiilor trombotice postsplenectomie (trombocitoza, splenomegalia, trombofilia) au fost analizați întrun alt studiu retrospectiv care a inclus 147 de pacienți şi au evidențiat o incidență de 5\% în dezvoltarea trombozei sistemului venos portal (14). În studiul prezent s-au înregistrat manifestări trombotice la un singur pacient, fiind vorba despre o adolescentă în vârstă de 16 ani cu politraumatism sever în urma unui accident rutier şi care a necesitat splenectomie de urgență. Ulterior a dezvoltat o formă severă de trombocitoză şi s-a pus în evidenţă un profil genetic pozitiv pentru trombofilie. Deşi nu există ghiduri care să recomande de rutină administrarea tromboprofilaxiei venoase la pacienții splenectomizați care dezvoltă trombocitoză, se recomandă administrarea de agenți antiplachetari la valori ale trombocitelor de peste 1,5 milioane $/ \mathrm{mm}^{3}$ în cazul asocierii unor factori de risc suplimentari (15). În cazul lotului nostru de studiu, 4 dintre pacienți au dezvoltat o formă severă de trombocitoză, cu valori de peste $1 \mathrm{milion} / \mathrm{mm}^{3}$, iar toți pacienții au primit Dipiridamol, ca şi măsură unică sau în asociere cu terapia anticoagulantă sau citoreductivă. În 2 cazuri s-a utilizat şi Hydreea (Hidroxiuree) pentru scăderea numărului de trombocite. În cazul etiologiei maligne, care de obicei asociază splenomegalie, precum şi la cazurile de splenectomie laparoscopică, dat fiind riscul crescut pentru tromboza venoasă (portală sau splenică), studiile au demonstrat că o anticoagulare cu heparină cu greutate moleculară mică timp de 30 de zile postoperator reprezintă o profilaxie benefică pentru pacienții selectați (16).

Trombocitoza postsplenectomie are o incidență maximă la 1-3 săptămâni după intervenție, cu revenirea lentă a valorilor normale în săptămâni, luni sau ani de zile (8). În lotul studiat, cel mai frecvent, momentul apariției trombocitozei a fost între ziua 2 şi ziua a 10-a postchirurgical, cu remisie în peste $80 \%$ dintre cazuri în primele 30 de zile.

\section{CONCLUZII}

Studiul de față întăreşte concluziile altor studii care dezbat aceeaşi tematică, şi evidențiază faptul că trombocitoza postsplenectomie este de cele mai multe ori benignă, iar tratamentul este o opțiune doar în cazuri selectate. Trombocitoza reactivă 
postsplenectomie a apărut la $80 \%$ dintre pacienții incluşi în studiu, independent de cauza subiacentă, forma severă de trombocitoză fiind mai frecventă în cazurile de natură traumatică. De cele mai multe ori (13 din cazuri), episodul s-a rezolvat spontan, hidratarea în asociere cu profilaxia antiagregantă şi anticoagulantă au fost singurele măsuri care s-au impus. Complicatiile trombotice au fost rare (un singur caz), asociind ca şi factor de risc predispoziția pentru trombofilie. 